\title{
What Is the Place of Conferences in the Training of Educators: A Case Study of Faculty of Education, METU
}

\author{
Melih N. Salman \\ Faculty of Sports Sciences, Aksaray University, Turkey
}

Copyright $\bigcirc 2019$ by authors, all rights reserved. Authors agree that this article remains permanently open access under the terms of the Creative Commons Attribution License 4.0 International License

\begin{abstract}
Teacher training and education is a very difficult and demanding process. Training qualified and elite teachers require even greater efforts. Today, training qualified and elite teachers cannot be achieved only by implementing the curricula to the letter. Curricula must be constantly supported with programs such as high level seminars, symposiums, workshops, etc. The aim of this study was to investigate the impact of such activities on the professional development of students. As part of a project called 'Community Leaders Are Coming' (CLC) conducted in cooperation between the Dean's Office of the Faculty of Education of Middle East Technical University (METU) and Çankaya Rotary Club, a series of seminars on education, science, arts, painting, music and sports were held in the past six weeks. In the seminars, 14 high level speakers specialised in their respective areas offered a total of 41 hours training that included visits to historical sites, opera and ballet performances, leadership training and practices. 136 students in the faculty of education joined the project, and 60 of them received a certificate after evaluations. Following the seminars, a 5-point Likert type questionnaire with 30 questions was administered to the participants to assess the project. The Cronbach's alpha internal consistency coefficient for the questionnaire was 0.82 . To analyse the data, the study used descriptive statistics, the Mann-Whitney U test and Kruskal Wallis test. The study found that the prospective teachers achieved significant professional learning outcomes through such activities and hoped that these programs would continue while they all agreed similar programs should be held also for students in other education faculties.
\end{abstract}

Keywords Students in the Faculty of Education, Education, Leadership, Seminar, Practical Training Professional Acquisition

\section{Instruction}

Establishing faculties of education were first attempted in Turkey in the 1950s, when Gazi Education Institute was designed to have a new structure to become a faculty of education, and at the same time, a similar approach was adopted in METU (Middle East Technical University), as well. All these attempts served their purpose, and a faculty of education was founded at METU in 1958. However, soon after that, the faculty turned into a department for teacher education within the Faculty of Science and Letters. In 1964, establishing a faculty of education at Ankara University was agreed, and this decision was also approved by the Ministry of Education [1-4]. Later, Istanbul University and Ege University followed this trend and established their own faculties of education. Today, with 64 faculties at state universities, 7 faculties at foundation universities, and 1 faculty at Faculty of Educational Sciences, there are totally seventy-two faculties of education in Turkey [3].

Today, it's a well-known fact that education is essential for a society or nation to sustain a modern way of life and ensure its social, cultural, and psychological continuity. The duty of educating new generation teachers that will later educate the youth is naturally a duty of faculties of education. Therefore, in order to educate the youth in a much better manner, it is imperative that the pre-service teachers in faculties of education not only receive very good education in their special field, but also have teaching profession knowledge and general cultural knowledge. Ornstein [5], argues that academic success shouldn't be considered as the sole important criterion while listing the characteristics of a good teacher. In addition to it, social and psychological traits such as maturity and a developed values structure should also be taken into consideration. Blasé [6], claims that an educational structure made up of monotype students is out of the question since today's students are going to work in various professions in the future and become doctors, engineers, lawyers, architects, teachers, etc. In this respect, he suggests that educating teachers with an approach that they can meet their students' different needs, interests and expectations is important.

According to Darling Hammond and Baratz-Snowden 
[7], the most significant aspect of teachers' professional development is educating them in a way that they can respond to different needs, abilities and expectations; and thus they could be able to educate their own students with a maximum level of success. Nowadays, teachers are basically expected to be more student-centered while teaching, make use of new teaching techniques more often, and take more responsibility at school [4-8]. In this respect, leadership quality of a teacher is the most necessary and essential factor for a teacher's success Blase [6], Bangs and Frost [9], Beycioğlu and Aslan [10], Can [11], Katzenmeyer and Moller, [12], Yorulmaz, at al.,[13]. Murtaugh [14], thinks that it won't be easy for pre-service teachers to develop all the above mentioned qualities only through field knowledge and teaching profession courses received at faculties of education.

If we examine the seminar topics that have been introduced by the universities in order to improve the qualifications of the prospective teachers of some universities in our country, it is seen that they have been diversified in a wide range: Voice and Education (Gazi University), Career Consultancy (Firat University, Elazı ğ), Contemporary Approach to Education Technology (Aydın University, İstanbul), Attention to Dyslexia (Artvin Çoruh University), Education of Teachers: Problems and Solution (Kafkas University, Kars), Seminar on Accessible Universities (Yıldırım Beyazıt University-Ankara), The Events of 1915 and What Happened Before (Nevşehir Hac1 Bektaş University - Nevşehir) etc. While seminars are given on different subjects/topics in universities where there are faculties of education, it is very important that the support by non-governmental organizations such as Education Reform Initiative (ERG), Çankaya Rotary Club (ÇRK) in terms of social and economic extent for the quality of the seminars and development of abilities and qualifications of the prospective teachers.

When we examine the world-recognized achievements in teacher training programs of some countries, it is obvious that the task of organizing and conducting education in Finland, which is at the top of the PISA (Programme for International Student Assessment) exams, is under the responsibility of local governments. In 1978, Finland's obligation for teachers to have master degree with thesis, and teachers has been obliged to achieve the teaching practice in four stages in two years. These kinds of tasks in education of teachers have played a crucial role in development of teachers' qualifications [15-16].

In Japan, prospective teachers have to take a proficiency exam, which includes general knowledge of culture, field and profession and three times a year in order to be a teacher. Prospective teachers who pass this exam are subject to a separate examination, which includes interviews and practice, and those who are successful in these exams are appointed as master teachers if they successfully complete the semi-annual internship period.

In Canada, the first condition that should be fulfilled by the teachers is to have advanced level for professional qualifications in order to be accepted as a teacher at the starting point and each state can set its own standards. For instance, the College of Teachers in British Columbia and Ontario, the State Standards Council in Alberta, has accredited teacher education programs and teacher professional development programs. In China, which overtakes the US and European countries in the PISA exam in 2009, the professional development and in-service trainings of the teachers have been under responsibility of the provincial education institutions of the universities supervised by the municipalities [17].

Considering all these views, it is obvious that educating teachers is highly difficult today and a completely satisfactory and meticulous program should be implemented [18-19-20-21]. According to Erdoğan, at al., [22], universities, and thus faculties of education, are responsible for increasing the efficiency of education in order to meet the expected learning objectives, designing favourable learning environments, and helping students benefit from these opportunities by means of organizing extra-curricular activities.

Binbaşığlu [1], Gökmenoğlu [23], and Köse [24] stated that extra-curricular activities contribute to academic success, perception of school culture, revelation and development of leadership skills, development of a sense of self, social and ethical development, productive use of leisure time, and adoption of a democratic attitude. Therefore, reinforcing the education of students in the faculties of education through extra-curricular activities (e.g. conferences, seminars, workshops, painting, art, music, trips, and cultural and sports activities) have utmost importance in order to provide pre-service teachers a broader vision. On top of everything, acknowledging the importance of the opportunities that their universities offer them for their self-development and learning qualities, students in faculties of education are also willing to spare time, energy, and effort for these kinds of activities. METU Faculty of Education carried out the 'Expanding Horizons and Leadership Training Program, also called CLC (Community Leaders Are Coming) in order to realize the above mentioned objectives, and contribute to the education of pre-service teachers so that they could be more qualified and have a broader vision. Also, volunteer non-governmental organizations (NGOs: Çankaya Rotary Club) undertook the execution and sponsorship of the program in order to assure that the program served its purpose.

This program, which was designed and prepared for all students in the faculty of education, was scheduled to be held at a six-week period from 10 March to 15 April 2017. Within the scope of the program, thirteen seminars, two leadership trainings, two field trips, and a performance show was carried out. All seminars were conducted at METU Kemal Kurdaş Cultural and Convention Center. The titles and main themes of these seminars and activities were as follows: 
The program administrators had nine prominent academicians (all of whom are specialized in the field of education and has had a number of scientific publications) give presentations on the seminar topics listed in Table 1. Among these, there are also educators who were awarded "The Best 50 Teachers of the World" in 2017. The required time to carry out all these activities was determined to be
46 hours.

In this study, all prospective teachers who participated in the whole series of seminars have been asked to evaluate each seminar separately and to determine the level of their achievements. They have been also asked to evaluate the preparation and implementation of the seminar to determine the overall success of the project.

Table 1. CLC 2017 Community leaders are coming' seminar/activity topics and main themes

\begin{tabular}{|c|c|c|}
\hline Title of the Seminar/Activity & Content and Main Theme of the Seminar/Activity & Time \\
\hline On the Life Ladder & Development, learning, and communication skills of school-age children & 2 hours \\
\hline First Step to Classical Music & How to listen to classical music and reflection of famous composers' lives on music & $\begin{array}{l}1,5 \\
\text { hours }\end{array}$ \\
\hline Educators' Communication Skills & How a teacher's communication skills should be and how to improve it & $\begin{array}{l}1,5 \\
\text { hours }\end{array}$ \\
\hline Çanakkale 1915: A path to the & $\begin{array}{l}\text { Developing awareness on recent history, and teaching Turkish history Republic of } \\
\text { Turkey }\end{array}$ & $\begin{array}{l}1,5 \\
\text { hours }\end{array}$ \\
\hline The Essence of a Good Teacher & A teacher's attitude towards students, and how to make use of teaching methods & $\begin{array}{l}1,5 \\
\text { hours }\end{array}$ \\
\hline My Life and Experiences as a Teacher & A teacher's attitude towards students, and how to make use of teaching methods & $\begin{array}{l}1,5 \\
\text { hours }\end{array}$ \\
\hline May I Do Sports, My Teacher?" & What should sports mean in your life as a teacher and in your students' lives? & $\begin{array}{l}1,5 \\
\text { hours }\end{array}$ \\
\hline A Single Wish is not Enough & $\begin{array}{l}\text { A teacher's successful applications in a multi grade class at a village school, and her } \\
\text { support and contribution to village life }\end{array}$ & 2 hours \\
\hline Education in Science Society & $\begin{array}{l}\text { Formation of the universe and the world, human evolution, and the future of humans in } \\
\text { the light of science }\end{array}$ & $\begin{array}{l}1,5 \\
\text { hours }\end{array}$ \\
\hline The Plums in Your Pocket & $\begin{array}{l}\text { New approaches in teaching primary school students, and how to instill a sense of } \\
\text { responsibility in them }\end{array}$ & $\begin{array}{l}1,5 \\
\text { hours }\end{array}$ \\
\hline Innovation in Production & $\begin{array}{l}\text { The importance of acoustics in learning environment, modern classroom } \\
\text { arrangements, and ergonomics of school material }\end{array}$ & $\begin{array}{l}1,5 \\
\text { hours }\end{array}$ \\
\hline Right Now... Why Not? & $\begin{array}{l}\text { How powerful should a teacher's communication skills be? Methods to open up new } \\
\text { horizons to students }\end{array}$ & 2 hours \\
\hline Leadership Applications & $\begin{array}{l}\text { What is leadership? What's the role of a leader? How to make use of group } \\
\text { organization and communication skills }\end{array}$ & $\begin{array}{l}1.5 \\
\text { hours }\end{array}$ \\
\hline $\begin{array}{l}\text { A Field Trip to the Sakarya Battle } \\
\text { Field in Polatl } 1\end{array}$ & Raising awareness on history, seeing the battlefields on site & 7 hours \\
\hline Harem Ballet Performance & Raising pre-service teachers' awareness on drama and performance arts & 3 hours \\
\hline Table Setting and Table Manners & Applied teaching of table manners and politeness & 1 hours \\
\hline Administrator and Leadership & How to make use of group organization and communication skills & 9 hours \\
\hline
\end{tabular}




\section{Method}

\subsection{Subjects}

In the Faculty of Education at METU, there are six departments, four of which offer undergraduate education and the other two offer graduate programs only. The undergraduate programs are Department of Computer Education and Instructional Technology (CEIT), Department of Mathematics and Science Education (MSE), Department of Elementary and Early Childhood Education (EECE), and Department of Foreign Language Education (FLE). All students having participated in this research were from Faculty of Education, METU and they took part on a volunteer and direct participation basis. The scope and content of the program was introduced to the students two weeks in advance through an event held in the faculty of education. Totally 136 students stated that they would attend the program and registered. Most of these were second-year, third-year and senior students, and they all participated voluntarily. As stated in the publicity event, students were expected to attend at least $70 \%$ of the activities in the whole program. At the end of the program, the students who attended the seminar programs and met the attendance requirements were given "Certificate of Participation" prepared by METU Faculty of Education and volunteer non-governmental organizations (NGOs.). Sixty students attended all the seminar series held during the whole course of the program. A questionnaire was developed for the students who were entitled to receive "Certificate of Participation", and they were asked to fill in the questionnaire and thus assess the whole program and their personal acquisitions, and to evaluate the success of the program. The aim of this practice was to get students' views on the program, to identify their satisfaction level, and to see in what specific topics their acquisitions was centered on.

The aim of this study was to identify students' views and level of satisfaction regarding such activities aimed at equipping students with skills required in performing the teaching profession, and to determine in which subjects their interest and learning outcomes concentrated.

\subsection{Data Collection and Its Analysis}

In order to obtain research data, "CLC Seminar Series Evaluation Questionnaire" was specially developed for this project based on expert's opinion; this survey is a special questionnaire, which was specifically designed for this research. The questionnaire was a five point Likert-type scale consisting of 30 questions. The format of the evaluation was designed to include five items which are (1) completely disagree, (2) disagree, (3) neither agree nor disagree, (4) agree, and (5) completely agree. The lowest score that can be obtained from the questionnaire was 30 while the highest score was 150 . The range of the 5-point Likert type scale was $5-1=4$, and interval coefficient was calculated as $(4 / 5=80)$. The scoring for the questionnaire was as follows: strongly disagree (1.00-1.80), disagree (1.81-2.60), somewhat agree (2.61-3.40), agree (3.41-4.20) and strongly agree (4.21-5.00). The questionnaire was initially designed as 34 questions, but after pre-implementation, a factor analysis was performed and 4 questions, which were thought to reduce reliability of the questionnaire, were omitted. When evaluated uni-dimensionally, it was found that the internal sensitivity coefficient (Cronbach's Alpha) of the questionnaire was 0.82 , which is a quite high value indicating that the internal consistency of the test is also high. The questionnaire consists of three sections. The first section, which includes the first 7 questions, covers technical issues such as timing of the program, its promotion, the use of communication channels, and efficacy of project announcement. 17 questions, each of which was on a different seminar topic, were asked in the second section in order that pre-service teachers evaluate their personal acquisitions from the seminar series and activities. In the last section, 6 questions were asked to specify the participants' opinions on maintaining the program in the future, and ensuring its sustainability in the following years.

SPSS 20 package program was used for identifying the data obtained out of the research. Descriptive statistical methods such as frequency, percentage value, arithmetic average, and standard deviation were used for the analysis of research data. To identify the difference between the groups, the study used the Mann-Whitney $U$ test and Kruskal Wallis test, both of which are parametric tests.

\section{Results}

Distribution of students having participated in the program by their departments can be seen in Table 2 . The highest participation was from Department of Mathematics and Science Education (MSE) with 58.0\%. It was followed by Department of Foreign Language Education (FLE) with $25.0 \%$, Department of Elementary and Early Childhood Education (EECE) with $11.0 \%$, and Department of Computer Education and Instructional Technology (CEIT) with $6.0 \%$.

When distribution of participating students was assessed according to their academic years, it was found that the highest participation rate was from third-year students with $41.2 \%$ followed by senior students with $29.4 \%$, second-year students with $22.1 \%$, and preparatory school students and freshman with $7.3 \%$. The majority of the participating students were female $(93.4 \%)$, and the rest was male students $(6.6 \%)$. 
Table 2. Demographic characteristics of the students in the faculty of education, METU

\begin{tabular}{|c|c|c|c|c|c|}
\hline & & \multicolumn{2}{|c|}{$\begin{array}{c}\text { The students having participated in the } \\
\text { program }\end{array}$} & \multicolumn{2}{|c|}{$\begin{array}{l}\text { The students having received a certificate of } \\
\text { participation }\end{array}$} \\
\hline & & $\mathrm{n}$ & $\%$ & $\mathrm{n}$ & $\%$ \\
\hline \multirow{4}{*}{ Section } & CEIT & 8 & 6.0 & 7 & 11.7 \\
\hline & MSE & 79 & 58.0 & 21 & 35.0 \\
\hline & MSE & 79 & 58.0 & 9 & 15.0 \\
\hline & FLE & 34 & 25.0 & 23 & 38.3 \\
\hline \multirow{4}{*}{ Class } & Pre and 1.Class & 10 & 7.3 & 3 & 5.0 \\
\hline & 2. Class & 30 & 22.1 & 11 & 18.3 \\
\hline & 3. Class & 56 & 41.2 & 15 & 25.0 \\
\hline & 4. Class & 40 & 29.4 & 31 & 51.7 \\
\hline \multirow{2}{*}{ Gender } & Female & 127 & 93.4 & 51 & 85.0 \\
\hline & Male & 9 & 6.6 & 9 & 15.0 \\
\hline Total & & 136 & 100.0 & 60 & 100.0 \\
\hline
\end{tabular}

$44.1 \%$ of the participating students received a certificate of participation. The students who had stated that they would attend the program but couldn't meet the $70.0 \%$ attendance requirement weren't given a certificate. The rate of female and male students having received certificate were $85.0 \%$ and $15.0 \%$, respectively. The low rate of male participant students resulted from the fact that the number of male students in faculties of education is generally low, rather than the fact that they weren't interested in the program. When distribution of students having received a certificate was assessed according to their academic years, it was found that the highest rate was from senior students with $51.7 \%$. On the basis of departments, the highest rate was from Department of Foreign Language Education (FLE) with 38.3\%, followed by Department of Mathematics and Science Education (MSE) with 35.5\%.

Distribution of the answers that the students in the faculty of education gave to the questions in CLC Seminar Evaluation Questionnaire can be seen in Table 3. When student's opinions on preliminary preparations of seminar series were examined, it can be seen that they chose $100 \%$ agree or completely agree $(\bar{x}=4.90 \pm 0.30) .76 .7 \%$ of the students agree that using What Sapp for keeping in contact during the course of the project is an effective method. $73.3 \%$ stated that the seminar topics in the project contributed to their personal development and the content of the program is appropriate for their professional development. $70.0 \%$ of the students found preparations and timing of the project appropriate. However, the rate of students who are in the opinion that the general announcement of the project is not timely and satisfactory was found as $70.0 \%$. In addition, $83.4 \%$ of the students asserted that it was a right choice to hold the project activities on weekends (on Saturdays and Sundays), since the project was an extra-curricular activity.

$100.0 \%$ of the students answered "Agree "or "Completely Agree" to the questions regarding the seminars "On the Life Ladder", which covers child development and psychology $(\bar{x}=4.90 \pm 0.30)$, “A Single Wish is not Enough" in which a teacher's efforts and ways to overcome challenges at a village school were told ( $\overline{\mathrm{X}}=$ $4.83 \pm 0.38)$, "Educators' Communication Skills" which is about the role of a teacher for communication $(\bar{X}=4.80 \pm$ 0.48 ), and the seminar "Right Now... Why Not?" ( $\bar{x}=$ $4.56 \pm 0.50)$. These results show that the students think the knowledge and acquisitions obtained out of these seminars were highly significant for their professional development.

Like these four seminars, which all students found profoundly effective in terms of their professional development and knowledge acquisition, the other eleven seminars were also highly approved $(93.4 \%)$ by the students in terms of the obtained acquisitions and their professional and personal development. 
Table 3. Distribution of students in the faculty of education by the answers that they gave to the CLC seminar series evaluation questionnaire

\begin{tabular}{|c|c|c|c|c|c|c|c|}
\hline & \multicolumn{7}{|c|}{$\begin{array}{l}\text { Evaluation Subject Level of Competence } \\
\text { The Lowest ( } 1 \text { ) The Highest (5) }\end{array}$} \\
\hline & $\begin{array}{l}1 \\
\mathrm{n} / \%\end{array}$ & $\begin{array}{l}2 \\
\mathrm{n} / \%\end{array}$ & \begin{tabular}{|l|}
3 \\
$\mathrm{n} / \%$
\end{tabular} & $\begin{array}{l}4 \\
\mathrm{n} / \%\end{array}$ & $\begin{array}{l}5 \\
\mathrm{n} / \%\end{array}$ & $\bar{X}$ & Sd \\
\hline \multicolumn{8}{|c|}{ Preliminary Evaluation of Pre-service Teachers on Seminar Series Preparations } \\
\hline 1. Seminar topics in the project are appropriate to the program content. & - & - & - & $\begin{array}{r}16 \\
26.7 \\
\end{array}$ & $\begin{array}{r}44 \\
73.7\end{array}$ & 4.73 & .45 \\
\hline 2. Timing of the project is appropriate & - & - & $\begin{array}{r}4 \\
6.7\end{array}$ & $\begin{array}{r}14 \\
23.3 \\
\end{array}$ & $\begin{array}{r}42 \\
70.0\end{array}$ & 4.63 & .61 \\
\hline 3. The days allocated for the project are suitable & - & - & $\begin{array}{r}10 \\
16.7\end{array}$ & $\begin{array}{r}16 \\
26.7\end{array}$ & $\begin{array}{r}34 \\
56.7 \\
\end{array}$ & 4.40 & .76 \\
\hline 4. The speakers chosen for the project are competent in their fields. & - & - & - & $\begin{array}{r}12 \\
20.0 \\
\end{array}$ & $\begin{array}{r}48 \\
80.0\end{array}$ & 4.80 & .40 \\
\hline 5. Project preparations are generally efficacious & - & - & $\begin{array}{r}2 \\
3.3 \\
\end{array}$ & $\begin{array}{r}16 \\
27.7\end{array}$ & $\begin{array}{r}42 \\
70.0\end{array}$ & 4.66 & .54 \\
\hline 6. General announcement of the project was timely and satisfactory. & - & $\begin{array}{r}6 \\
10.0 \\
\end{array}$ & $\begin{array}{r}12 \\
20.0 \\
\end{array}$ & $\begin{array}{r}20 \\
33.3 \\
\end{array}$ & $\begin{array}{r}22 \\
36.7 \\
\end{array}$ & 3.97 & .99 \\
\hline $\begin{array}{l}\text { 7. Using the What's App application for Project announcement before each activity was effective in terms of providing } \\
\text { effective communication }\end{array}$ & - & - & $\begin{array}{r}2 \\
3.3 \\
\end{array}$ & $\begin{array}{r}12 \\
20.0\end{array}$ & $\begin{array}{r}46 \\
76.7 \\
\end{array}$ & 4.73 & .52 \\
\hline \multicolumn{8}{|c|}{ Evaluation of the Pre-service Teachers' Acquisitions Obtained out of the Seminar Series and Activities } \\
\hline 8. The knowledge to be acquired through the speech "On the Life Ladder" is essential for my profession. & - & - & - & $\begin{array}{r}6 \\
10.0\end{array}$ & $\begin{array}{r}54 \\
90.0\end{array}$ & 4.90 & .30 \\
\hline 9. The knowledge to be acquired through the speech "First Step to Classical Music" is essential for my profession. & - & - & $\begin{array}{r}2 \\
3.3 \\
\end{array}$ & $\begin{array}{r}44 \\
73.3 \\
\end{array}$ & $\begin{array}{r}14 \\
23.4 \\
\end{array}$ & 3.87 & .89 \\
\hline $\begin{array}{l}\text { 10. The knowledge to be acquired through the speech “Educators' Communication Skills" is essential for my } \\
\text { profession. }\end{array}$ & - & - & $\begin{array}{r}2 \\
3.3\end{array}$ & $\begin{array}{r}8 \\
13.3 \\
\end{array}$ & $\begin{array}{r}50 \\
83.4\end{array}$ & 4.80 & .48 \\
\hline $\begin{array}{l}\text { 11. The knowledge to be acquired through the speech "Çanakkale 1915: A path to the Republic of Turkey" is essential } \\
\text { for my profession }\end{array}$ & - & $\begin{array}{r}4 \\
6.7 \\
\end{array}$ & - & $\begin{array}{r}16 \\
26.7\end{array}$ & $\begin{array}{r}40 \\
66.7\end{array}$ & 4.53 & .81 \\
\hline 12. The knowledge to be acquired through the speech "Administrator and Leadership" is essential for my profession & - & - & $\begin{array}{r}4 \\
6.7\end{array}$ & $\begin{array}{r}14 \\
23.3\end{array}$ & $\begin{array}{r}42 \\
70.0\end{array}$ & 4.63 & .61 \\
\hline 13. The knowledge to be acquired through the speech "The Essence of a Good Teacher" is essential for my profession & - & - & $\begin{array}{r}4 \\
6.7 \\
\end{array}$ & $\begin{array}{r}10 \\
16.7 \\
\end{array}$ & $\begin{array}{r}46 \\
76.6 \\
\end{array}$ & 4.63 & .80 \\
\hline $\begin{array}{l}\text { 14. The knowledge to be acquired through the speech "My Life and Experiences as a Teacher" is essential for my } \\
\text { profession }\end{array}$ & - & - & $\begin{array}{r}4 \\
6.7 \\
\end{array}$ & $\begin{array}{r}14 \\
23.3 \\
\end{array}$ & $\begin{array}{r}42 \\
70.0\end{array}$ & 4.63 & .61 \\
\hline 15. The knowledge to be acquired through the speech "May I Do Sports. My Teacher? " is essential for my profession & - & $\begin{array}{r}2 \\
3.3 \\
\end{array}$ & $\begin{array}{l}- \\
-\end{array}$ & $\begin{array}{r}17 \\
28.4 \\
\end{array}$ & $\begin{array}{r}41 \\
68.3 \\
\end{array}$ & 4.60 & .67 \\
\hline 16. The knowledge to be acquired through the speech "A Single Wish is not Enough" is essential for my profession & - & - & - & $\begin{array}{r}10 \\
16.7 \\
\end{array}$ & $\begin{array}{r}50 \\
83.3 \\
\end{array}$ & 4.83 & .38 \\
\hline 17. The knowledge to be acquired through the speech "Education in Science Society" is essential for my profession & - & $\begin{array}{r}8 \\
13.3 \\
\end{array}$ & $\begin{array}{r}14 \\
23.3 \\
\end{array}$ & $\begin{array}{r}12 \\
20.0 \\
\end{array}$ & $\begin{array}{r}26 \\
43.3 \\
\end{array}$ & 3.93 & 1.1 \\
\hline 18. The knowledge to be acquired through the speech "The Plums in Your Pocket" is essential for my profession & - & $\begin{array}{r}2 \\
3.3 \\
\end{array}$ & $\begin{array}{r}2 \\
3.3 \\
\end{array}$ & $\begin{array}{r}12 \\
20.0 \\
\end{array}$ & $\begin{array}{r}44 \\
73.3 \\
\end{array}$ & 4.63 & .71 \\
\hline
\end{tabular}




\begin{tabular}{|c|c|c|c|c|c|c|c|}
\hline 19. The knowledge to be acquired through the speech "Innovation in Production" is essential for my profession & - & $\begin{array}{r}14 \\
23.3 \\
\end{array}$ & $\begin{array}{r}10 \\
16.7\end{array}$ & $\begin{array}{r}22 \\
36.7 \\
\end{array}$ & $\begin{array}{r}14 \\
23.3 \\
\end{array}$ & 3.46 & 1.3 \\
\hline 20. The knowledge to be acquired through the speech "Right Now... Why Not?" is essential for my profession & - & - & - & $\begin{array}{r}26 \\
43.3 \\
\end{array}$ & $\begin{array}{r}34 \\
56.7 \\
\end{array}$ & 4.56 & .50 \\
\hline 21. "A Field Trip to the Sakarya Battle Field" and similar activities should be included in following CLC programs. & - & $\begin{array}{r}4 \\
6.6 \\
\end{array}$ & $\begin{array}{l}- \\
-\end{array}$ & $\begin{array}{r}10 \\
16.7 \\
\end{array}$ & $\begin{array}{r}466 \\
76.7 \\
\end{array}$ & 4.57 & 1.6 \\
\hline 22. "Table Setting and Table Manners" and similar activities should be included in following CLC programs. & - & $\begin{array}{r}2 \\
3.3 \\
\end{array}$ & $\begin{array}{r}6 \\
10.0 \\
\end{array}$ & $\begin{array}{r}8 \\
13.3 \\
\end{array}$ & $\begin{array}{r}44 \\
73.3 \\
\end{array}$ & 4.53 & .03 \\
\hline 23. "Leadership Applications" and similar activities should be included in following CLC programs & - & $\begin{array}{r}2 \\
3.3 \\
\end{array}$ & $\begin{array}{r}2 \\
3.3 \\
\end{array}$ & $\begin{array}{r}8 \\
13.4 \\
\end{array}$ & $\begin{array}{r}48 \\
80.0 \\
\end{array}$ & 4.67 & .84 \\
\hline 24. "Harem Ballet Performance" and similar activities should be included in following CLC programs & - & $\begin{array}{r}2 \\
3.3 \\
\end{array}$ & $\begin{array}{r}4 \\
6.7 \\
\end{array}$ & $\begin{array}{r}14 \\
23.3 \\
\end{array}$ & $\begin{array}{r}40 \\
66.7 \\
\end{array}$ & 4.50 & .89 \\
\hline \multicolumn{8}{|c|}{ General Evaluation of Pre-service Teachers on Sustainability of the Seminar Programs } \\
\hline $\begin{array}{l}\text { 25. I consider the cooperation of volunteer non- governmental organizations (NGOs) and METU Faculty of Education } \\
\text { for organizing }\end{array}$ & - & - & $\begin{array}{r}2 \\
3.3\end{array}$ & $\begin{array}{r}8 \\
13.3 \\
\end{array}$ & $\begin{array}{r}50 \\
83.3\end{array}$ & 4.80 & .48 \\
\hline 26. I believe this program open up new horizons for pre-service teachers & - & - & - & $\begin{array}{r}4 \\
6.7 \\
\end{array}$ & $\begin{array}{r}56 \\
93.3\end{array}$ & 4.93 & .25 \\
\hline 27. I'm contended to have attended this program & - & - & - & $\begin{array}{r}4 \\
6.7\end{array}$ & $\begin{array}{r}56 \\
93.3\end{array}$ & 4.93 & .25 \\
\hline 28. I can recommend this program to my friends & - & - & - & $\begin{array}{r}10 \\
16.7 \\
\end{array}$ & $\begin{array}{r}50 \\
83.3\end{array}$ & 4.83 & .38 \\
\hline 29. The program must be implemented in all faculties of education & - & - & - & $\begin{array}{r}2 \\
3.3 \\
\end{array}$ & $\begin{array}{r}58 \\
96.7\end{array}$ & 4.96 & .18 \\
\hline 30. The program has raised my awareness on volunteer non-governmental organizations (NGOs) & - & - & - & $\begin{array}{r}14 \\
23.3\end{array}$ & $\begin{array}{r}46 \\
76.7\end{array}$ & 4.77 & .43 \\
\hline
\end{tabular}


The two seminars that were also considered to be highly effective by the students were "Administrator and Leadership" ( $\bar{x}=4.63 \pm 0.61)$ and "The Essence of a Good Teacher" $(\bar{x}=4.63 \pm 0.80)$, in both of which a teacher's leader role at school and in public was discussed and behaviours of the teachers with this influence were specified. Besides, it was found that "The Plums in Your Pocket" $(\bar{X}=4.63 \pm 0.71)$, in which a primary school teacher's experiences, the responsibilities that he instilled in his students beginning from the early days of his career, and these students nationwide success were told, and "My Life and Experiences as a Teacher" which was about a retired teacher's professional life and his first year in teaching, equally influenced the students in faculty of education $((\bar{x}=4.63 \pm 0.71)$ and $(\bar{x}=4.63 \pm 0.61)$, respectively).

"May I Do Sports, My Teacher?", where the determining role of sports in child development and the reasons why sports should be a routine part of our daily lives was discussed, also drew great interest $(\bar{x}=4.60 \pm 0.67)$. It was followed by "Harem Ballet Performance" $(\bar{x}=4.50 \pm 0.89)$ at State Opera and Ballet, Ankara with an attendance rate of $90.0 \%$. "First Step to Classical Music", in which how to listen to classical western music and reflection of famous composers' lifestyles on their musical works were mentioned, attracted great attention with a close rate of $96.7 \%(\bar{x}=3.87 \pm 0.89)$.

$80 \%$ of the students having attended at least five different activities on "Leadership Applications" reported that these activities provided them significant professional acquisitions and a new point of view $(\bar{x}=4.67 \pm 0.84)$. It was followed by "Table Setting and Table Manners" with an $86.6 \%$ appreciation rate $(\bar{x}=4.53 \pm 0.3)$.

93.4 of the students agreed that the two on site field trip activities, namely "Çanakkale 1915: A path to the Republic of Turkey", through which the Çanakkale War - a war with a crucial role in foundation and recent history of our country- and its outcomes were told strategically, and "A Field Trip to the Sakarya Battle Field" helped them better understand the importance of both wars in Turkish history and raised their awareness on history $(\overline{\mathrm{X}}=4.53 \pm 0.81)$ and $(\bar{x}=4.57 \pm 1.03)$, respectively).

The seminars that the students found to be less beneficial in terms of opening up new horizons and providing knowledge and experience were listed as "Education in Science Society" $(\bar{x}=3.93 \pm 1.10)$ and "Innovation in Production" $(\overline{\mathrm{x}}=3.46 \pm 1.32)$.

Table 4. Mann-Whitney U Test Results on Total Scores of the Study Group Based on Gender

\begin{tabular}{|l|l|l|l|l|l|}
\hline Gender & $\mathrm{n}$ & Mean Rank & Sum of Ranks & $\mathrm{U}$ & $\mathrm{P}$ \\
\hline Male & 9 & 25,83 & 232,50 & 187,500 &, 381 \\
\hline Female & 51 & 31,32 & 1597,50 & & \\
\hline
\end{tabular}

The result of the Mann-Whitney $U$ test conducted to determine whether there was any difference in total scores of the female and male students in the faculty of education obtained from the seminars indicated there was no statistically significant difference based on gender
$(\mathrm{U}=187.500, \mathrm{p}>0.05)$

Table 5. Kruskal Wallis Test Results on Total Scores of the Study Group Based on Department

\begin{tabular}{|l|l|l|l|l|l|}
\hline Department/Section & $\mathrm{n}$ & Mean Rank & $\mathrm{Sd}$ & $\mathrm{X}$ & $\mathrm{P}$ \\
\hline BÖTE & 7 & 27,21 & 3 & 3,264 & 3,53 \\
\hline MFE & 21 & 30,07 & & & \\
\hline TEB & 9 & 39,83 & & & \\
\hline YDE & 23 & 28,24 & & & \\
\hline
\end{tabular}

The result of the Kruskal Wallis test performed to see whether total scores of the students obtained from the seminars differed significantly in relation to department showed that there was no statistically significant difference between the departments $(X, s d, n=60)=3.264, p>0.05$. Accordingly, total scores of the prospective students did not differ based on the department variable.

Table 6. Kruskal Wallis Test Results on Total Scores of the Study Group Based on Grade

\begin{tabular}{|l|l|l|l|l|l|}
\hline Class & $\mathrm{n}$ & Sira Ortalamalar1 & $\mathrm{Sd}$ & $\mathrm{X}$ & $\mathrm{P}$ \\
\hline Pre. and 1. Class & 3 & 10,50 & 3 & 11,159 &, 011 \\
\hline 2. Class & 11 & 23,59 & & & \\
\hline 3. Class & 15 & 26,03 & & & \\
\hline 4. Class & 31 & 37,05 & & & \\
\hline
\end{tabular}

There was a statistically significant difference between the groups in terms of total scores based on grade $(\mathrm{X}, \mathrm{sd}$, $\mathrm{n}=60)=11.159, \mathrm{p}<0.05$. From prep class and $1^{\text {st }}$ year to upper classes, the level of satisfaction and total scores of the groups increased. Accordingly, it was found that senior students achieved highest learning outcomes from the seminars

The rate of the students considering the cooperation of volunteer non-governmental organizations (NGOs) and METU Faculty of Education for organizing this project as important was $96.6 \%(\bar{x}=4.80 \pm 0.48) .100 .0 \%$ of the students stated that this project enabled them to raise their awareness on Rotary and gain more information about it $(\bar{x}$ $=4.77 \pm 0.43)$. In addition, all of the students declared that they were glad to have participated in this project $(\bar{x}=4.93$ \pm 0.25 ).

It was found that $100 \%$ of the students having attended the program answered, "Agree" or "Completely Agree" to the questions 26,28 , and $29(\bar{x}=4.96 \pm 0.18)$, which means they believe this program opens up new horizons and it should definitely be extended to all faculties of education in our country, and they will recommend the program to their friends.

When the evaluation of evaluations of prospective teachers about the preparation of seminars ( 7 items), it has been found that their satisfaction with the preparation of seminar has had a very high average $(\bar{x}=4.56 \pm 0.61)$. A similar result has been obtained for the evaluation of the individual gains obtained from the seminars and activities $(\bar{X}=4.24 \pm 0.43)$. Apart from the seminars titled as "the First Step to Classical Music", "Innovation in Production" 
and "Education in Science Society" the seminars and activities are above the average. These situations can be explained with the chosen topics/subjects and the acceptance of the prospective teachers by the experts in a high level. Likewise, when the opinions of the prospective teachers about the continuity of the seminar programs are evaluated ( 6 items, $\bar{x}=4.87 \pm 0.33$ ), it has been concluded that they are very willing to ensure the continuity of the program. In general, it can be stated that all the phases of the seminar program have been found as successful and efficient/ beneficial by the prospective teachers.

\section{Discussion}

This project, also called CLC (Community Leaders Are Coming), was designed and prepared for students at Faculty of Education, METU. Held between March - April 2017in cooperation and under the sponsorship of METU Faculty of Education and volunteer non-governmental organizations (NGOs: Çankaya Rotary Club), it should be regarded as part of extra-curricular activities. Its aim was to provide pre-service teachers more professional competence and a new perspective and horizon, and to help them become much stronger in their profession.

Within the scope of the project, thirteen seminars, two leadership trainings, two field trips, and a performance show were carried out. All of these were provided by education specialists and scientists who have novel and up-to-date approaches in their fields and a number of publications and conference participations.

$44.1 \%$ (60 people) of the students who are enrolled in the seminar program are eligible. $42.7 \%$ (58 people) participated in all seminars except 1-2 seminar subjects. After each presentation, the prospective teachers actively participated in the question and answer session with the invited speakers/lecturers/debaters. Among the reasons that students who participated in the seminar series but did not participate in the program $(13.2 \%)$ and who have difficulty in attendance to the seminar, have problems about the time schedule of the program, internship, preparation for exams, obligation to go out of the province etc. can be listed. The high level of participation of the third class has been seen as a result of the increasing sensitivity in the teaching profession and as a result of the positive feedback they received from their peers who participated in this seminar series in previous years. In the age of information technology, it is a well-known fact that the concept of education in the world has gone through a fundamental change and is still changing at a rapid pace. In this respect, it is imperative that teacher education programs also be changed, renewed, and improved in accordance with the changes and developments in communication and information technology [3]. The fast process of change witnessed today has caused expansion of teachers' assigned duties and has given them much more responsibilities, which in turn shifted their role from knowledge providers to facilitators who assist their students in learning processes, leaders who guide students in every respect in conformity with the needs of the time, communicators who can keep easy and constant communication with their students, and adaptable individuals who can easily adjust to new environments Council of Higher Education [3], Beycioğlu, at al [10], Erdoğan et al[22], Beydoğan [25], Bircan [26], Ministry of Education [27], TED [28], Yildıran [29]. Today, the characteristics of a good teacher also include the ability (i) to provide guidance in physics education, sports, painting art, music, folklore and other social areas as well as social sensitivity, (ii) to help students become involved in such kinds of activities, (iii) and to bring out students' talents and abilities in those areas. Since pre-service teachers who will educate the youth will also have a significant role in shaping the future, attaining the qualities required for performing those duties in a proper and timely manner must be considered as vital.

In a study carried out by the Ministry of Education in 2006, the six main general teaching profession competencies were declared. These are professional development, knowing about students, learning and teaching process, monitoring and evaluating learning and development, school-parent and society relations, and knowledge about program and content. In addition to them, 39 sub-competencies and 244 performance indicators were also determined. It is obvious that all these competencies cannot be attained only through the courses in education and teaching programs. Therefore, supporting pre-service teachers with extra-curricular activities should be considered as an inevitable and compulsory part of their education. When the students' answer to our questionnaire was evaluated, it can be clearly seen that they benefited greatly from almost all aspects of the project in general. No statistically significant difference was found in total scores of the students for the seminars in relation to gender and department variables $(p>0.05)$. However, as for the grade variable, it was found that there was an obvious increase in total scores beginning from prep class and first year as well as a significant difference between the groups $(\mathrm{p}<0.05)$. This result may be interpreted as that the education offered to students has increased their professional awareness, and students have increased knowledge over time and feel more ready to perform their profession

The seminar subjects that drew the attention of the prospective teachers most were child development and psychology, and the experiences of a village teacher about how a positive change occurred in children and their families in the village as result of the teacher's endeavours. They were followed by seminars on the techniques for communication between the teacher and students. The leadership role of teacher in school and society, how and in what way students should be given responsibility, and the impact of sports on child development were also among the 
subjects that attracted a great deal of attention in the seminars. The study finding indicating that there was a high level of satisfaction ranging between $\bar{x}=4.90 \pm 0.30$ and $\bar{X}=4.50 \pm 0.89$ for 14 out of 17 seminar subjects can be considered as an indicator that the project achieved its purpose.

The results have shown that the appreciation rate was above $50 \%$ even for the two seminars namely "Education in Information Society" $(\overline{\mathrm{x}}=3.93 \pm 1.10)$ and "Innovation in Production" ( $\bar{x}=3.46 \pm 1.32)$ from which the students stated that they had benefited less. The underlying reason for lower satisfaction rates for "Education in Information Technology" is thought be its content. In that seminar, formation and development of the Earth and humanity were discussed scientifically, which might have been perceived as an anti-thesis against the dogmas on this issue. Likewise, "Innovation in Production" presents a new scientific approach on technical issues such as the importance of acoustics in classrooms, its impact on learning, and developments in school and classroom arrangements; therefore, the students might have failed to fully grasp it.

However, it can be easily said that the project was found highly successful, and the students in the faculty of education were contended with it in general, and showed great interest and participation. They stated that CLC project opened up new horizons to them, and they will recommend such kind of projects to their friends. Besides, their opinion that the project must be carried out in all faculties of education nationwide emphasizes the importance of professional responsibility and extra-curricular activities, because it is obvious that in our age that all kinds of effort are required to be equipped by the prospective teachers to have knowledge and skills in national and international fields. Mehmetlioğlu [30], Senemoğlu [31] Erel [32] and Işıktaş [33] have concluded that the deficiencies in gaining teaching skills and especially implementation in their research on prospective teachers affect qualification. Therefore, in addition to updating the Faculty of Education programs, it is inevitable to support the prospective teachers for their readiness and development of teaching profession in each year with a highly qualified seminar, conference, workshop etc.

\section{Conclusions}

Abazoğlu et al. [34] argues, "In this information age, almost everyone agrees on the importance of more free and powerful humans. Today's dilemma on teacher education is going to be the society's dilemmas in the future. The answer to the question 'what kind of an education is required' lies in the question 'what kind of a teacher is required'."

As a result, when looked at from this perspective, it can be seen that contribution of extra-curricular activities, conferences, seminars and social activities to teacher education programs is highly appreciated by students. At this point, the educational administrators are expected to maintain and increase the number of high quality educational events that will help pre-service teachers have a better perception of a good teacher's qualities and be more competent in their profession when they graduate.

\section{REFERENCES}

[1] Binbaşığlu, C. (2000). Başlangıçtan Günümüze Türk Eğitim Tarihi, Genişletilmiş 2. Baskı, Anı yayıncılık.

[2] Mihçığlu, C. Eğitim (Bilimleri) Fakültesinin Kuruluşu Üzerine,

http://dergiler.ankara.edu.tr/dergiler/40/511/6314.pdf

(Access Date: 16.12.2017).

[3] Council of Higher Education, YÖK (2006). Eğitim Fakültelerinde Uygulanacak Yeni Programlar Hakkında Açıklama,http://www.yok.gov.tr/documents/10279/49665/ aciklama_programlar/aa7b09 1-9328-4df7-aafa-2b99edb6 872f (Access Date: 11.11.2017).

[4] Bek, Y. (2007). Öğretmenin Toplumsal / Mesleki Rolleri ve Statüsü. Trakya Üniversitesi Sosyal Bilimler Enstitüsü, Eğitim Bilimleri ABD, Kasım 2007. Yüksek Lisans Dönem projesi, Edirne 2007.

[5] Ornstein, A.C. (1976). Can we define a good teacher. Peabody Journal of Education, 53 (3), 201-2007.

[6] Blase, J. (1986). Socialization as Humanization: One side of becoming a teacher Sociology of Education, 59(2), 100-113.

[7] Darling-Hammond, L. \& Baratz-Snowden, J. (2005). A Good teacher in every classroom: Preparing the highly qualified teachers our children deserve. San Francisco, CA: Jossey-Bass.

[8] Frost, D. \& Roberts, A. (2014). The Role of Teacher Leadership in Education Reform: Mobilizing moral purpose, Paper presented in the European Conference on Educational Research, (ECER 2014) Porto.

[9] Bangs, J. \& Frost, D. (2012). Teacher self-Efficacy, Voice and Leadership; towards a policy framework educational international. http://download.ei-ie.org/Docs/Web Depot/ teacher_self efficacy_voice_leadership. Pdf

[10] Beycioğolu, K. \& Aslan, B., Öğretmen ve Yöneticilerin Öğretmen Liderliğine Ilişkin Görüşleri, Educational Administration Theory and Practice, 18(2), 191-223.

[11] Can, N. (2009). Öğretmenlerin sinıfta ve okulda liderlik davranışlarl, Gaziantep Üniversitesi Sosyal Bilimler dergisi, 8(2), 385-399.

[12] Katzenmeyer, M. \& Moller, G. (2013). Uyuyan Devi Uyandırmak Öğretmen Liderler Yetiştirmek, Nobel Yayıncılık, Ankara. 2103.

[13] Yorulmaz, İ. Y., Altınkurt, Y. \& Y1lmaz, K. (2015). The relationship between teacher's occupational 
professionalism and organizational alienation. Education Process: International Journal (EDUPIJ), 4(1-2), 31-44.

[14] Murtaugh, M. (1988). Achievement outside the classroom: The role of nonacademic activities in the lives of high school students. Anthropology \& Education Quarterly 19 (4), 382-395.

[15] Ekinci, A. \& Öter, Ö. M. (2010). Finlandiya'da eğitim ve ögretmen yetiştirme sistemi, (çalışma ziyareti raporu), Kasim 2010.

[16] Elçiçek, Z. \& Yaşar, M. (2016). Türkiye'de ve Dünyada ögretmenlerin mesleki gelişimi. The teachers' professional development in Turkey and World, Electronic Journal of Education Science, 5(9), 12-19.

[17] Zhu, X., Han, X. (2006). Reconstruction of the teacher education system in China. International Education Journal, 7(1), 66-73. http://eric.ed.gov/?id=EJ847303 (Access Date: 28.09.2018).

[18] [Arslan, H. \& Uslu, B. (2014a). Öğretmen adaylarının liderlik yönelimlerinin incelenmesi. e-International Journal of Education Research, 5(1), 41-60

[19] Aydın, R., Bozkuş, T. \& Kul, M. (2016). Beden eğitimi ve spor yüksekokullarındaki öğrencilerin liderlik özelliklerinin cinsiyet değişkenine göre incelenmesi, International Journal of Science Culture and Sport. (IntJSCS), 4(3), 122-131

[20] Garipağaoğlu, B. Ç. \& Güloğlu, B. (2015). Öğretmen adaylarında öz liderlik becerilerinin yordayıcısı olarak ögrenilmiş güçlülük ve denetim odağ , Abant İzzet Baysal Üniversitesi Eğitim Fakültesi Dergisi, 15(2), 147-162.

[21] Turan, M. B., Erol, Z \& Karaoğlu, B. (2016). Beden eğitimi ve spor ögretmenliğ $i$ bölümünde okuyan ögrencilerin liderlik düzeylerinin ögretmenlik mesleği yordama gücünün incelenmesi, Spor Bilimleri Dergisi, 6(3),71-78.

[22] Erdoğan, M., Uşak, M. \& Aydın, H. (2008). Investigating prospective teachers' satisfaction with social services and facilities in Turkish universities. Journal of Baltic Science Education, 7(1), 17-26.

[23] Gökmenoğlu, T. \& Kiraz E. (2011). Öğretmen Adaylarının Üniversitelerde Sunulan Sosyal ve Akademik Olanaklarl Değerlendirme Durumları: ODTÜ Örneği, Türk Eğitim Bilimleri Dergisi, Bahar, Say1 9(2), 393-410.

[24] Köse, E. (2013). Eğitim Kurumlarında Gerçekleștirilen Ders Dışı Etkinliklerin Sinıflandırllmasına Yönelik Bir Öneri, Uluslararası Türkçe Edebiyat Kültür ve Eğitim Dergisi, Say1 2(2), 336-353.

[25] Beydoğan, Ö. (2002). Öğretim Stratejilerindeki Değişmeler ve Ögrretmenlerin Değişen Rolleri, Çağdaş Eğitim, 27(287), 34-39.

[26] Bircan, İ. (2003). Eğitimde Yeni Yönelimler. Gelişmiş Ülkelerde Sinıf Öğretmeni Yetiștirme Uygulamaları, Eğitimde Yansımalar, 7. Çağdaş Eğitim Sistemlerinde Öğretmen Yetiştirme Ulusal Sempozyumu Bildiriler Kitabı, Cumhuriyet Üniversitesi s. 44-47.

[27] Oddens, D.A.M. (2004). Kişilik Nitelikleri Açısından Hollanda'da Mesleki Ĕgitim İçin Öğretmen Eğitimi Eğilimleri, Mesleki ve Teknik Eğitimde Öğretmen Eğitimi Uluslararası Konferans1, Ankara, s. 37-44.
[28] MEB (2006). Öğretmenlik Mesleği Genel Yeterlilikleri, http://oygm.meb.gov.tr/meb_iys_dosyalar(/2017_12/1316 1921_Ögrretmenlik_Mesleği_Genel_yeterlikleri_onaylana n.pdf (Access Date: 14.12.2017).

[29] TED (2009). Türk Ĕ̌̆itim Derneği, Öğretmen yeterlilikleri, http://portal.ted.org.tr/ yayinlar/Ogretmen_Yeterlik_Kitap. pdf (Access Date: 16.12.2017).

[30] Yıldıran, G. (2010). Öğretmen Ĕ̈itimi Üzerine Düşünceler, Boğaziçi Üniversitesi Eğitim Dergisi, 27(2).

[31] Mehmetlioğlu, D. (2010). Investigating the readiness of preservice mathematics teachers towards teaching profession. Unpublished Master's Thesis, Middle East Technical University.

[32] Senemoğlu, N. (2003). Türkiye'de sınıf ögrretmeni yetiştirme uygulamaları, sorunları, öneriler. Süleyman Demirel Üniversitesi, Burdur Eğitim Fakültesi Dergisi, 5, 154-193.

[33] Eret, E. (2013). Hizmet öncesi öğretmen eğitiminin öğretmen adaylarını mesleğe hazırlama bakımından değerlendirmesi, ODTÜ Sosyal Bilimler Enstitüsü, Eğitim Bilimleri ABD. Yayınlanmamış Doktora Tezi, Mayıs 2013, Ankara.

[34] Işıktaş, S. (2015). Öğretmen adaylarının iyi öğretmen olma ile ilgili görüşleri, Hacettepe Üniversitesi Eğitim Fakültesi Dergisi ( H.U. Journal of Education) 30(4): 119-131.

[35] Abazaoğlu, İ., Yıldırım, O. \& Yıldızhan, Y. (2016). Geçmişten Günümüze Türk Ĕ̈itim Sisteminde Öğretmen Yetiştirme, Uluslararası Türk Eğitim Bilimleri dergisi, 4(6) 143-160. 